\title{
PERUBAHAN DESAIN BUSANA ADAT PENGANTIN WANITA DI KOTA PARIAMAN SUMATERA BARAT
}

\author{
Cindi Harmelia $^{1 *}$, Yuliarma ${ }^{2 *}$ \\ Pendidikan Kesejahteraan Keluarga Jurusan Ilmu Kesejahteraan Keluarga Fakultas Pariwisata dan Perhotelan \\ Universitas Negeri Padang \\ Jl. Prof. Dr. Hamka, Air Tawar Padang, Kel. Air Tawar Barat, Kec. Padang Utara, Kota Padang, Kode Pos 25131 \\ Sumatera Barat. Indonesia \\ Email:cindyharmelia567@gmail.com,yuliarmaincim@yahoo.com
}

\begin{abstract}
Abstrak
Penelitian ini bertujuan untuk mendeskripsikan perubahan desain baju pengantin wanita di Kota Pariaman meliputi siluet, bentuk, bahan, warna, motif serta teknik hias. Selain itu terdapat pelengkap, aksesoris, cara pakai dan makna estetis yang terkandung didalamnya. Metode penelitian ini adalah penelitian deskriptif kualitatif dengan jenis data primer dan sekunder. Data dikumpulkan dengan menggunakan teknik observasi, wawancara dan dokumentasi. Analisis data menggunakan teknik pengumpulan analisis interaktif yang berkaitan dengan pokok permasalahan yang diteliti. Hasil penelitian menunjukkan bahwa 1) Baju atas tradisional wanita disebut dengan baju kuruang basiba serta baju bawah dengan kain balapak mengalami perubahan desain dari segi siluet yang dahulunya I sekarang menjadi siluet A.Bentuknya berupa baju lapang dan longgar, namun sekarang berubah dengan baju yang memperlihatkan"lekuk tubuh. Bahan yang dahulu satin dan songket Pandai Sikek, diganti dengan bahan beludru, mikado dan songket silungkang. Baju tradisional berwarna merah dan emas menjadi merah tua, maupun biru dengan hiasan berwarna emas.Motif baju asli yaitu bungo batabua berubah menjadi motif flora dan dekoratif.Teknik hias yang dahulunya menggunakan sulaman benang emas dan kepala peniti, sekarang adalah bordiran dan payet; 2) Pelengkap baju terdiri dari tokahyang dahulu berbentuk seperti selendang, sekarang memiliki bentuk seperti segitiga yang menggantung dibahu. Suntiang, tradisional memiliki tujuh jenis terpisah sekarang ini dirangkai menjadi satu kesatuan utuh yang menyatu. Selop kolom juga mengalami perubahan sedikit pada bagian warna, bahan, dan penambahan hak; 3) Aksesoris pengantin tradisional terdiri dari 5 kalung, 5 gelang, dan sebuah ranai, sekarang hanya menggunakan satu jenis kalung, sebuah ranai dan gelang dengan model terkini; 4) Cara pakai busana mengalami perubahan seperti pemasangan baju atas, tokah, dan suntiang. Sedangkan pada baju bawah, selop kolom dan aksesoris pemasangannya sama dengan busana tradisional dan; 5) makna estetika yang ada pada busana pengantin wanita saat masa sekarang yang telah mengalami perubahan menjadi hilang, ini dikarenakan berubahnya komponen dari setiap bagian busana.
\end{abstract}

Kata Kunci: perubahan desain, busana pengantin, Pariaman.

\begin{abstract}
This research aims to describe changes in the design of brides' clothes in Pariaman City including silhouettes, shapes, materials, colors, motifs and ornamental techniques. In addition there are complements, accessories, ways of use and, aesthetic meaning contained in it. This research method is qualitative descriptive research with primary and secondary data types. Data is collected using observation, interview and documentation techniques. Data analysis uses interactive analysis collection techniques related to the subject matter being studied. The results showed that 1) Women's traditional top clothes are called kuruang basiba clothes and lower clothes with racing fabrics undergo design changes in terms of silhouettes that were once I is now silhouette A. The shape is in the form of airy and loose clothes, but now changed with clothes that show"of the body. Materials that used to be satin and songket Pandai Sikek, replaced with velvet, mikado and songket silungkang. Traditional clothes are red and gold to be dark red, or blue with gold decorations. The original clothing motif that is bungo batabua turned into a flora and decorative motif. Ornamental techniques that used to use gold thread embroidery and pinheads, are now embroidery and sequins; 2) The complement of clothes consists of tokah that was onceshaped like a shawl, now has a triangular-like shape that hangs in the shoulder. Suntiang, traditionally has seven separate types now assembled into one whole unified unity. Columnelop also undergoes slight changes in the color, material, and addition of rights; 3) Traditional bridal accessories consistingof 5 necklaces, 5 bracelets, and a ranai, now using only one type of necklace, a ranai and bracelet with the latest model; 4) How to wear clothes undergo changes such as the installation of top clothes, tokah, and suntiang. While on the bottom shirt, the column and installation accessoriesare the same as traditional clothing and; 5) The aesthetic meaning that exists in the bride's fashion at this time
\end{abstract}


that has undergone changes becomes lost, this is due to the change in components of each part of the fashion.

Keywords: design change, bride's attire, Pariaman.

\section{PENDAHULUAN}

Pakaian merupakan benda kebudayaan yang tinggi dan penting untuk semua suku yang ada dibelahan dunia manapun. Pakaian adatmenurut Mutia dalam Gusparini (2014: 22) adalah "Pakaian yang dipakai secara turun"temurun, yang"merupakan salah satu identitas diri dan"menjadi kebanggaan"bagi sebagian besar masyarakat pendukung kebudayaan tersebut". Masingmasing pakaian adat memilikikeunikan yang disebabkan oleh perbedaan kebiasaan"yang terdapat di dalam masyarakat daerah itu sendiri.

Busana pengantin wanita di Minangkabau, khususnya di daerah pesisir (Pariaman) mempunyai keunikan yang diintepretasikan sebagai identitas budaya khas daerah Minang. Pakaian adat pengantin Pariaman ditinjau dari perspektif adat Minangkabau"akan memperlihatkan pesandan nilai budaya masing-masing seperti ekonomi, sosial, politik dan"keagamaan. Pesan tersebut akan dapat diketahui"melalui simbol, warna dan ragam hias pada pakaian. Kelengkapan pakaian adat pengantin wanita itu sendiri yaitu terdapatnyasuntiang (penutup kepala), baju dan kain songket, dan dilengkapi dengan aksesorisguna menambah kesan keindahan pada pakaian tersebut (Asnan, 2003: 23).

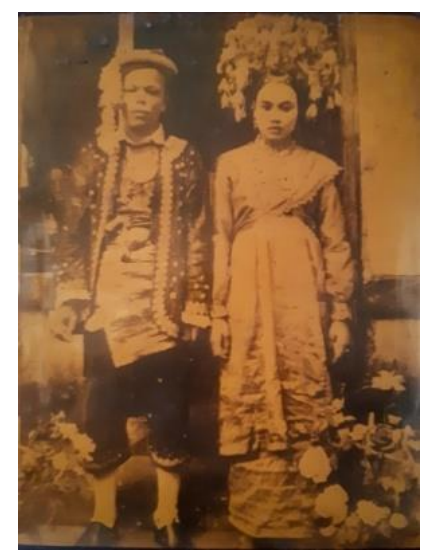

Gambar 1. Model Asli Busana Pengantin Tradisional Pariaman tahun 1950

Gambar 1 memperlihatkan model busana pengantin Kota Pariaman pada tahun 1950-an sampai tahun 1990an dan model"busana pengantin tersebut saat ini hampir tidak pernah dikenakan lagi oleh pengantin masa sekarang. Seiring dengan perkembangan zaman dan perubahan selera masyarakat saat ini, busana pengantin di Pariaman masa sekarang juga sudah mengalami perubahan.
Wawancara dengan Bundo Kanduang Kota Pariaman ibu Arrahmi tanggal 20 September 2020 menjelaskan "busana adat pengantin memang jarang ditemukan. Dahulu menggunakan baju kuruang basiba dan kain balapak, tetapi sekarang baju dibuat dengan bahan yang sama dengan bawahnya."

Selain itu wawancara dengan ibu Zahirma Kamili selaku sekretaris Bundo Kanduang Kota Pariaman pada 22 September"2020 menjelaskan busana pengantin sekarangjauh berbeda dengan baju asli. Jika dahulu penggunaan tokah berupa selendang panjang tidak ada lagi. Baju warna merah dengan tokah hijau sekarang sudah jauh berbeda. Hal ini dikarenakan keinginan masyarakat untuk tampil lebih modern.

\section{KAJIAN TEORI}

\section{Konsep Perubahan}

Proses perubahan pasti didalamnya ada jangka waktu atau kurun waktu tertentu, yang kedua itu berkaitan dengan jangka waktu perubahan sosial dimasyarakat, yaitu evolusi dan revolusi. Hal tersebut mendorong masyarakat maupun sistem sosial yang ada untuk menyesuaikan diri dengan lingkungan (Eisenstadt, 1986: 7).

Perubahan budaya'akan terus terjadi dengan kebutuhan masyarakat, dengan kemajuan teknologi yang membuat kebutuhan semakin meningkat sehingga mempengaruhi budaya yang ada. (Koentjaraningrat, 1994: 9).

Maka dapat disimpulkan bahwa perubahan terjadi"akibat perkembangan zaman dari waktu ke waktu"serta keinginan'untuk memenuhi kebutuhan didalam kehidupan sehingga mempengaruhi budaya yang ada.

\section{Unsur-unsur Busana Pengantin}

Menurut Yuliarma (2016: 1) "busana merupakan semua'benda yang dipakai"mulai dari kepala sampai"ujung kaki"yang menampilkan keindahan dan"keserasian. Busana"terdiri dari”tiga unsur yaitu busana"bersifat pokok seperti kebaya, baju kurung dll, busana"bersifat pelengkap berupa jam, ikat pinggang,"alas kaki, dan"busana bersifat"menambah"keindahan"(aksesoris) seperti anting, cincin. 
Gorga : Jurnal Seni Rupa

Volume 10 Nomor 02 Juli-Desember 2021

p-ISSN: 2301-5942 | e-ISSN: 2580-2380

Busana yaitu"semua yang"digunakan"mulai dari kepala sampaiujung kaki"yang menampilkan keindahan meliputi"busana pokok, pelengkap dan aksesoris (Arifah, 2003: 2).

Berdasarkan pendapat diatas dapat disimpulkan bahwa"busana merupakan"segala sesuatu"yang dipakai mulai dari kepala"hingga kaki yang meliputi busana"pokok, pelengkap"dan aksesoris.

\section{Desain Busana Pengantin}

\section{1). Desain Struktur}

Desain"struktur merupakan wujud suatu benda. Berupa susunan garis, bentuk, tekstur,"warna, bahan dari"suatu benda yang berbentuk"3 dimensi"maupun bentuk gambar dari suatu"benda. (Sawitri, 1994: 51).

Selain itu berdasarkan pendapat Widarwati (1993: 2) bahwa desain struktur merupakan desain yang diciptakan sesuaitekstur,"bentuk, baik mempunyai ruangmaupun gambaran"suatu benda. Pada"busana desain"struktural disebut dengan"siluet"yang merupakan bentuk dasar suatu busana.

Berdasarkan pendapat tersebut dapat diambil kesimpulan bahwa desain struktur merupakan suatu karya yang terlahir dari kreativitas atau pemikiran manusia yang berupa siluet, bentuk, bahan dan warna.

\section{2). Desain Hiasan}

Desain hiasan adalah desain yang berfungsi untuk memperindah permukaan dari desain struktur seperti sulaman, bordir, terawang, mote-mote, pita, dan sebagainya (Yuliarma, 2016:3).

Sedangkan menurut"Ernawati (2008: 384) desain hiasan merupakan desain yang meningkatkan mutu dari desain struktur suatu benda. Selain itu menurut Widarwati (1993:5) menjelaskan bahwa desain hiasan berbentuk krah, saku, biku-biku, sulaman, lipit, dan lain-lain.

Berdasarkan pendapat diatas maka dapat disimpulkan bahwa desain hiasan berupa ornamen, motif-motif ataupun ragam hias yang dapat meningkatkan mutu dari desain struktur.

\section{Cara Pakai}

Yasin (1997: 90) berpendapat bahwa "cara merupakan"metode atau strategi'untuk"melakukan suatu tindakan atau kebiasaan. Dalam'penggunaan busana"pada upacara biasanya menggunakan perhiasan milik keluarga yang diatur cara penggunaannya.
Berdasarkan pendapat ahli diatas dapat disimpulkan bahwa cara memakai adalah suatu langkah-langkah ataupun tata cara berbusana disebuah upacara"pernikahan sesuai hukum adat yang ada.

\section{Makna Estetis}

Menurut Ullman dalam"Pateda (2001: 82) makna"merupakan sebagai"hubungan antara makna"dan pemahaman. Aminuddin (2003: 13) menyampaikan "bahwa"makna adalah"hubungan antara bahasa"dan dunia"luar, serta"pengguna bahasa saling bersepakat sehingga"memahami satu sama lain.

Berdasarkan pendapat diatas"maka dapat disimpulkan bahwa"makna adalah nilai-nilai dan makna yang terkandung didalam kehidupan manusia dan menjadi"pesan dan pedoman untuk menjalani kehidupan.

\section{METODE PENELITIAN}

Jenis penelitian"ini adalah penelitian deskriptif kualitatif. Penelitian deskriptif menurut Sugiyono (2014: 83) yaitu penelitian yang berusaha mendeskripsikan"suatu gejala, peristiwa, kejadian yang terjadi saat"sekarang. Penelitian deskriptif memusatkan perhatian kepada masalah-masalah aktual sebagaimana adanya padasaat penelitian"berlangsung. Teknik pengumpulan data"penelitian ini berupa observasi langsung, wawancara, dan dokumentasi. Sehingga pada penelitian ini mendesktipsikan perubahan desain baju, pelengkap, aksesoris, cara pakai dan makna yang terkandung didalam busana pengantin wanita Pariaman.

\section{HASIL DAN PEMBAHASAN}

\section{Hasil}

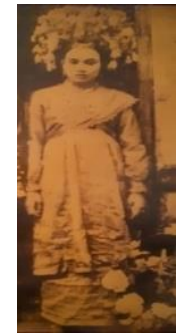

Gambar 2. Busana Pengantin Tradisional Wanita di Kota Pariaman

Berikut merupakan bentuk perubahan busana pengantin wanita di Kota Pariaman. 


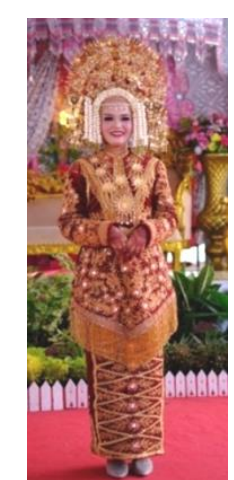

Gambar 3. Model 1

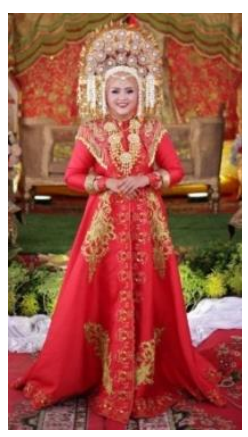

Gambar 4. Model 2

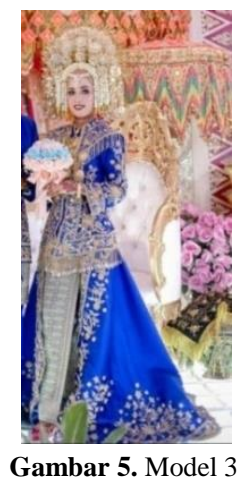

\section{1). Perubahan Desain Baju Pengantin Wanita di Kota Pariaman}

\section{(1). Siluet}

Busana pegantin wanita Pariaman yang tradisionalmemiliki bentuk yang lurus mulai dari atas hingga bawah dengan siluet I. namun pada masa sekarang ini busana pengantin memiliki berbagai macam bentuk siluet, ada yang masih menggunakan siluet Iseperti pada busana pengantin model 1 dan ada menggunakan siluet A seperti busana model 2 dan 3 .

\section{(2). Bentuk}

Bentuk busana pengantin tradisional yaitu lapang dan longgar, baju atas memiliki panjang hingga dibawah lutut, belahan pada garis leher seperti segitiga dengan panjang $8 \mathrm{~cm}$, lengan suai dengan panjang sampai pergelangan tangan. Baju bawah berupa kain dengan panjang $95 \mathrm{~cm} \times 158 \mathrm{~cm}$.
Gorga : Jurnal Seni Rupa

Volume 10 Nomor 02 Juli-Desember 2021 p-ISSN: 2301-5942 | e-ISSN: 2580-2380

Pada busana model 1 memiliki belahan memakai resleting pada belakang baju. Bawah baju dengan potongan berbentuk $\mathrm{V}$, lengan suai, dan garis leher bulat. Kain berbentuk persegi panjang dengan ukuran $98 \mathrm{~cm} \times 160 \mathrm{~cm}$.

Baju model 2 berbentuk seperti dress panjang hingga lantai. Terdapat belahan pada bagian depan menggunakan kancing. model lengan suai dan terdapat kerah.

Sedangkan model 3 memiliki panjang baju sepanggul dengan belahan menggunakan kancing pada bagian depan. Lengan suai hingga pergelangan tangan dan kerah sanghai. Menggunakan songket dengan ukuran $96 \times 160 \mathrm{~cm}$.

\section{(3). Bahan}

Busana pengantin tradisional berbahan satin untuk baju atas dan baju bawah menggunakan kain songket pandai sikek.Busana model 1 menggunakan bahan beludru. Selain itu busana model 2 dan 3 untuk baju atas menggunakan bahan Mikado dan songket dari Silungkang. Pada busana model 3 terdapat baju bawah bagian luar menggunakan bahan Mikado.

\section{(4). Warna}

Ernawati (2008: 76) berpendapat warna merupakan untuk desain yang paling menonjol. Dengan adanya warna menjadikan suatu benda dapat dilihat. Busana pengantin wanita di Pariaman berwarna merah dan emas. Namun sekarang memiliki berbagai macam warna seperti pada busana model 1 menggunakan warna merah tua serta busana model 3 berwarna biru dengan hiasan berwarna emas. Sedangkan busana model 2 tetap menggunakan warna merah seperti pada busana tradisional.

\section{(5). Motif}

Motif merupakan bagian dari ragam hias, Menurut Yuliarma (2016: 69) ragam hias dibedakan menjadi tiga kelompok, yaitu geometris, naturalis dan dekoratif. Motif yang digunakan pada busana pengantin asli menggunakan motif bungo batabua dan motif kain yaitu pucuak rabuang, salapah-salapah, saluak laka dan bungo tanjuang. Busana model 1 menggunakan motif flora dan pucuak rabuang. Pada busana model 2 baju atas bermotif dekoratif dan baju bawah bermotif pucuak rabuang, salapah-salapah dan itiak pulang patang. Sedangkan pada busana model 3 baju atas dan baju bawah bagian luar dengan motif flora, pada kainnya bermotif salapah-salapah, pucuak rabuang, dan biku-biku. 
(6). Teknik Hias

Busana pengantin tradisional wanita menggunakan teknik hias sulaman benang emas dan kepala peniti. Sedangkan pada perubahan busana pengantin model 1,2 dan 3 menggunakan teknik hias bordiran dan hiasan payet-payet.

\section{2). Perubahan Pelengkap Pengantin Wanita di Kota Pariaman}

Pelengkap adalah segala sesuatu yang dapat melengkapi busana pengantin. Menurut Rostamilis (2005: 172) millineries atau pelengkap busana adalah semua yang dapat melengkapi dan berguna bagi sipemakai. Pelengkap pada busana baju penagntin wanita di Kota Pariaman adalahtokah, selop kolom dan suntiang.

\section{(1). Tokah}

Tokah pada busana pengantin lama berbentuk selendang panjang berwarna hijau berbahan satin dengan hiasan sulaman benang emas pada ujungnya. Sedangkan sekarang tokah berbentuk seperti segitiga menggantung pada bahu menggunakan bahan, warna, motif, serta hiasan bordir dan payet yang sama dengan bajunya.

\section{(2). Selop Kolom}

Selop kolom busana pengantin trasional wanita memiliki bagian depan tertutup, berwarna merah, bahan satin, berhiaskan sulaman benang emas dan kepala peniti. Perubahan yang terjadi pada sandal ini adalah penggunaan bahan dan warna serta penambahan hak pada tapak sendal.

\section{(3). Suntiang}

Suntiang asli memiliki 7 jenis yaitu sarunai, kotekote,buruang tajun, suntiang gadang, sinar blog, mansi-mansi, dan sepasang burung merak. Berwarna emas dan memiliki berat sekitar $3-5 \mathrm{~kg}$. Suntiang sekarangmengalami perubahan dimana ia dirangkai menjadi satu. Sehingga pemasangannya jadi lebih mudah dan lebih ringan.

\section{3). Perubahan Aksesoris Pengantin Wanita di Kota Pariaman}

Aksesoris menurut Yuliarma (2016: 2) adalah benda yang berfungsi sebagai penambah keindahan dalam berbusana. Pada busana pengantin wanita Pariaman aksesoris yang digunakan adalah kalung, gelang dan ranai.

\section{(1). Kalung}

Kalung dahulu terdiri dari 5 jenisyaitu kalunggadang, rago-rago, cakiak, pinyaram dan rumah adat. Masa sekarang hanya menggunakan kalung 1 jenis yaitu kalung pinyaram.

\section{(2). Gelang}

Busana pengantin tradisiona wanita di Kota Pariaman menggunakan aksesoris berupa gelang yang teridiri atas 5 macam, yaitu gelang ula, rago-rago, gadang, pilin, dan gubala. Gelang terbuat dari tembaga yang disepuh emas. Namun pada masa sekarang penggunaan gelang tidak sebanyak ini lagi. Bahkan busana model 1 tidak menggukan gelang. Pada busana model 2 menggunakan gelang gadang dan gelang yang bukan gelang khas Pariaman. Sedangkan gelang pada busana model 3 yaitu gelang yang terbuat dari bahan titanium berwarna emas.

\section{(3). Ranai}

Masa dahulu ranai memiliki desain yang sederhana dan ukurannya kecil, terbuat dari loyang yang disepuh emas. Untuk sekarang desain yang sekarang memiliki bentuk dan ukuran yang bermacam-macam. Pada seleliling ranai dihiasi dengan permata, serta tanai terbuat dari bahan tembaga dan titanium berwarna emas.

\section{4). Perubahan Cara Pakai Busana Pengantin Wanita di Kota Pariaman}

Jika diurutkan pemakaian busana pengantin wanita di Pariaman dimulai dari memakai baju bawah, baju atas, tokah, suntiang, semua aksesoris dan yang terakhir memasang sandal. Hal ini berlaku untuk busana pengantin tradisional maupun busana pengantin masa sekarang.

Perubahan terjadi pada pemasangan tokah yang tradisional disilangkan didada, sekarang"ini tokah hanya diletakkan pada sekeliling leher dan menggantung pada bahu. Lalu pemasangan suntiang yang dipasangkan dengan cara ditusuk pada sanggul yang terbuat dari irisan daun pandan dan dibungkus menggunakan plastik. Sekarang ini penggunaan suntiang lebih praktis hanya dengan cara diletakkan diatas kepala lalu diikat dengan tali kemudian menggunakan jepitan agar tidak mudah lepas. Selain itu penggunaan komponen lainnya sama antara busana tradisional dengan masa sekarang.

\section{5). Makna Busana Pengantin Wanita di Kota Pariaman}

Baju kuruang basiba bermakna perempuan harus memiliki hati yang lapang dan berjiwa luas dan mampu mengontrol emosi. Kain balapak berarti bahwa perempuan harus bijaksana dalam mengambil suatu keputusan. Pada kain terdapat motif pucuak rabuang 


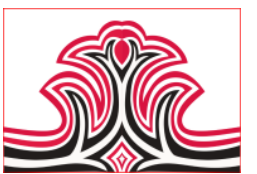

yang memiliki arti bahwa perempuan harus berguna bagi kehidupan keluarganya dan sebagai seorang istri harus dapat taat kepada suami.

Selain itu ada bagian pelengkap seperti tokah bermakna bahwa perempuan yang menikah akan menopang beban berat pada bahunya untuk menjalani kehipan berumah tangga. Terdapat sandal yang pada bagian depannya tertutup bermakna wanita harus bisa merahasiakan kehidupan berumah"tangganya. Suntiang yang memiliki berat $3-5 \mathrm{~kg}$ berarti beratnya beban yang akan ditanggung perempuan saat ia menikah.

Kemudian aksesoris berupa kalung bermakna bahwa wanita berada"didalam lingkaran yang benar, ia harus bisa menegakkan kebenaran didalam suatu keluarga. Sedangkan gelang bermakna"seorang wanita"ia harus bisa memilah hal yang patut untuk disampaikan kepada orang.

Busana pengantin masa sekarang yang telah mengalami perubahan membuat makna yang terkandung didalam setiap"bagian busana menjadi hilang. Hal yang dipertahankan"sampai sekarang yaitu motif pucuak rabuang pada baju bawah.

\section{Pembahasan}

Tabel 1. Sketsa Baju

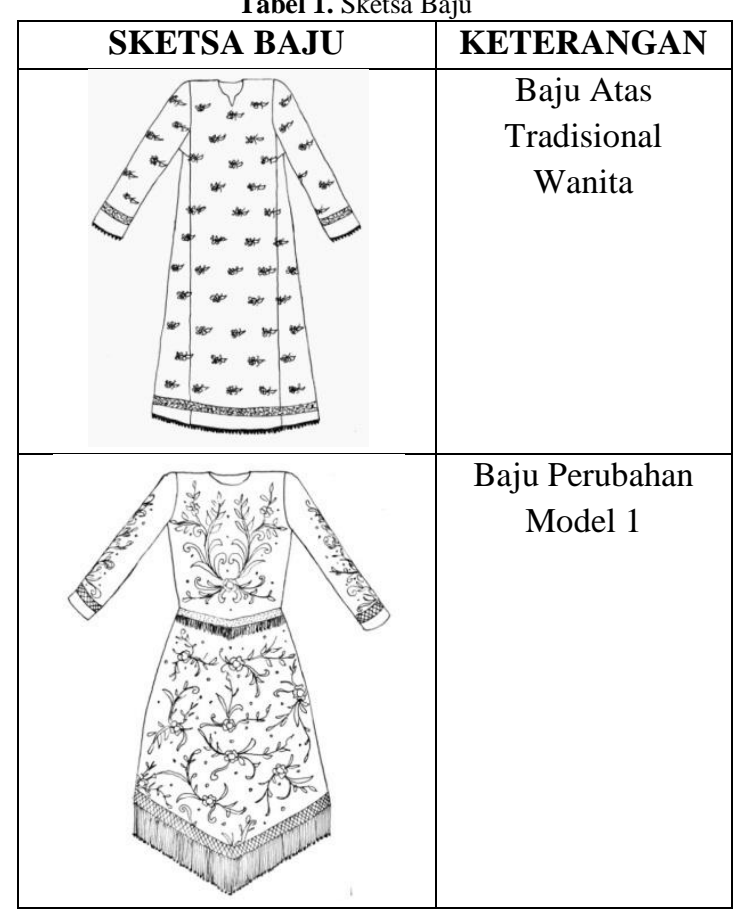

Gorga : Jurnal Seni Rupa

Volume 10 Nomor 02 Juli-Desember 2021 p-ISSN: 2301-5942 | e-ISSN: 2580-2380

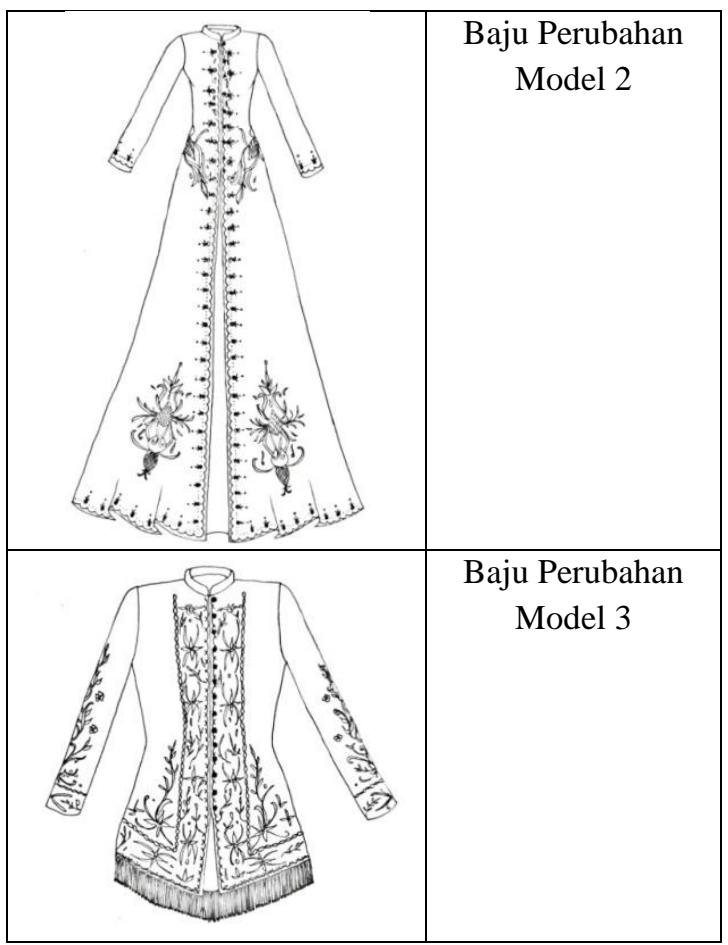

Dapat dilihat bahwa busana mengalami perubahan yang cukup besar dari waktu ke waktu yang membuat busana tradisional wanita tidak ada lagi ciri khas yang masih dipertahankan. Baik pada desain baju, pelengkap, aksesoris dan pada cara pemakaian serta maknanya.

\section{KESIMPULAN DAN SARAN}

\section{Kesimpulan}

Baju yang digunakan oleh pengantin wanita di Kota Pariaman saat sekarang ini memang telah mengalami perubahan. Jika dahulunya busana berbentuk baju kurung, sekarang berbentuk blus ataupun dress. Busana sekarang mengalami perubahan baik dari segi siluet, bentuk, warna, bahan, motif,dan teknik hias.Pelengkap dan aksesoris pengantin wanitajuga mengalami perubahan. Cara pemakaian busana pengantin memiliki beberapa perubahan dalam penggunaannya. Seperti pada pemasangan tokah dimana dahulunya dipasangkan dengan cara menyilang pada bagian dada, namun tokah masa sekarang dipasang dengan cara diletakan saja pada bahu. Busana pengantin tradisional wanita di Pariaman memiliki arti dan makna yang terkandung didalamnya yang menjadi pesan untuk kehidupan masyarakat khususnya di Kota Pariaman. Jika bagian tersebut berubah maka makna yang terkandung menjadi hilang.

\section{Saran}

Diharapkan kepada pemerintah Kota Pariaman untuk lebih mengenalkan busana pengantin wanita kepadamasyarakat seperti mengadakan acara pawai 


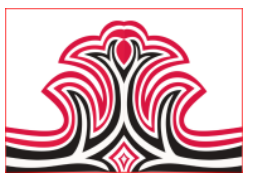

atau parade. Serta kepada masyarakat untuk menggunakan busana pengantin tradisional saat melaksanakan pernikahan untuk melestarikan budaya didaerah kita.

\section{DAFTAR RUJUKAN}

Aminuddin. (2003). Semantik Pengantar Studi tentang Makna. Malang: Sinar Baru Agesindo.

Arifah. (2009). Dasar Desain Mode. Bandung: Universitas Pendidikan Indonesia.

Asnan, Gusti. (2003). Kamus Sejarah Minangkabau. Padang: Pusat Pengkajian Islam dan Minangkabau (PPIM).

Eisenstadt, S.N. (1986). Revolusi dan Transformasi Masyarakat. Terjemahan Chandra Johan. Jakarta: CV. Rajawali.

Ernawati, dkk. (2008). Tata Busana Jilid 2. Jakarta: Direktorat Pembinaan Sekolah Menengah Kejuruan.

Gusparini, Rela. (2014). Tinjauan Pakaian Adat Bundo Kanduang di Kanagarian Koto Tinggi Kecamatan Baso Kabupaten Agam Sumatra Barat. (Skripsi). Padang: Program Strata I Universitas Negeri Padang.

Koentjaraningrat. (1994).Kebudayaan Mentalitas Dan Pembangunan. Jakarta: Gramedia Pustaka Utama.

Pateda, Mansoer. (2001). Semantik Leksikal. Jakarta: Rineka Cipta.

Rostamilis. (2005). Tata Kecantikan Rambut Jilid 3. Jakarta: Direktorat Pembinaan Sekolah Menengah Kejuruan.

Sawitri, Sicilia. (1994). Tailoring. Yogyakarta: IKIP Yograkarta.

Sugiyono. (2014). Metode Penelitian Kuantitatif Kualitatif dan R\&D. Bandung: Alfabeta.

Widarwati, Sri. (1993). Desain Busanal. Yogyakarta: IKIP Yogyakarta.

Yasin, Sulchan. (1997). Kamus Pintar Bahasa Indonesia. Surabaya: Amanah.

Yuliarma. (2016). The Art of Embriodery. Jakarta: KPG.

. (2016). Dasar-Dasar Teknik Pembuatan

Busana. Edisi Pertama. Jakarta: Perpustakaan Nasional: Katalog Dalam Terbitan (KDT). 